\title{
The Effect of Change in Posture on Spirometry in Patients with Obstructive Sleep Apnoea Syndrome
}

Redha Al Lawati, ${ }^{1}$ "Mohammed A. Al Abri, ${ }^{2}$ Balaji Kuppuswamy, ${ }^{2}$ Amira Al-Kharousi, ${ }^{2}$ Al Yaqdhan Al-Atbi, ${ }^{1}$ Syed Rizvi, ${ }^{3}$ Mohan Dikshit ${ }^{4}$

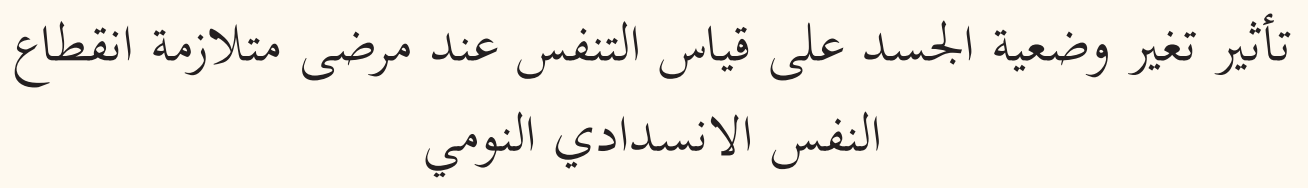

رضا اللواتي، محمد عبداله العبري، بالاجي كويوسوامي، أميرة الخروصية، اليقظان العتبي، سيد رزفي، موهـان ديكشيت

ABSTRACT: Objectives: Obstructive sleep apnoea syndrome (OSAS) is a growing health concern as it is associated with serious comorbidities. OSAS is mainly related to obesity, age, gender and a narrowed upper airway is commonly seen in patients with OSAS. This study aimed to compare spirometry parameters between obese OSAS patients and non-obese OSAS patients when patients moved from sitting to supine. Methods: This cross-sectional study was conducted at Sultan Qaboos University Hospital, Muscat, Oman, between December 2009 and December 2010. Patients with severe OSAS and who were OSAS treatment naïve were recruited. Spirometry was performed in all patients in sitting and supine positions to assess forced vital capacity (FVC), forced expiratory volume in the first second (FEV1), FEV1/FVC, forced expiratory flow (FEF) 50\%, FEF 25-75\%, maximum forced inspiratory flow and expiratory reserve volume. The mean difference in spirometry parameters between patients in sitting and supine positions was calculated. Results: A total of 27 OSAS patients (19 males and 8 females) were included in this study. There was a significant difference in FEV1/FVC in obese and non-obese patients when changing position $(P=0.03)$. In addition, there was a significant change between male and female patients' FVC percentages $(P<0.05)$. Male patients with OSAS had reduced FVC compared to females. There was no significant difference in the remaining spirometry parameters with patients' change of position. Conclusion: A supine position may cause lower airway obstruction in obese patients with OSAS. The reduced FVC in males possibly contributes to the high prevalence of OSAS in men compared to women.

Keywords: Obstructive Sleep Apnea; Obesity; Gender; Spirometry; Posture; Oman.

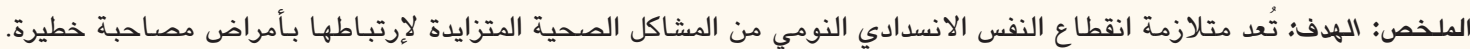

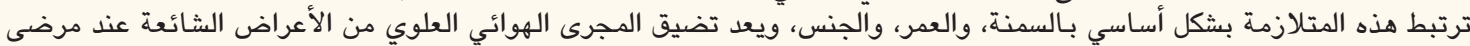

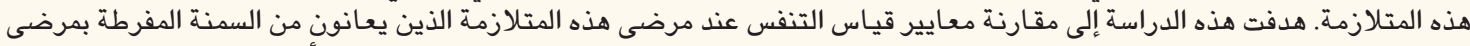

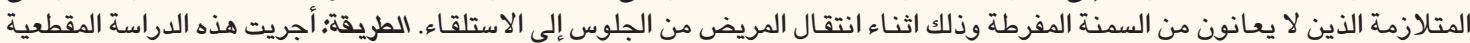

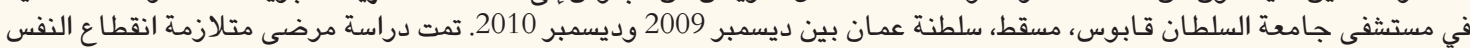

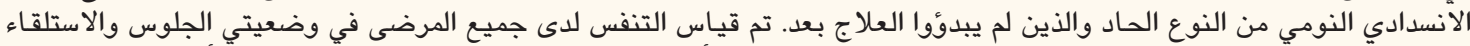

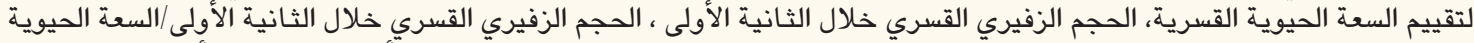

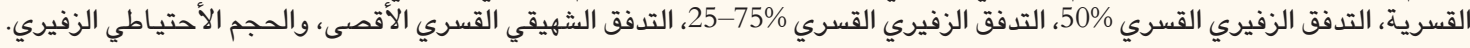

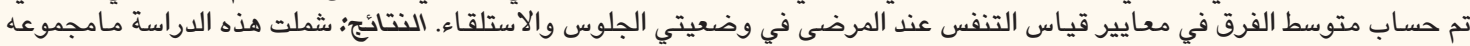

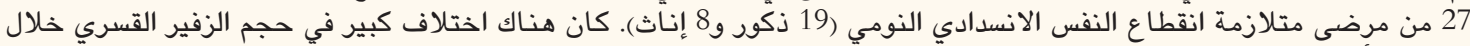

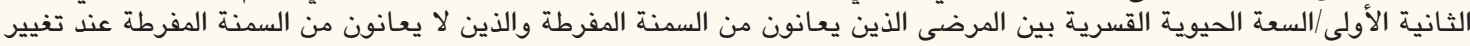

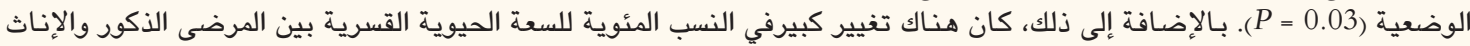
(P<0.05)

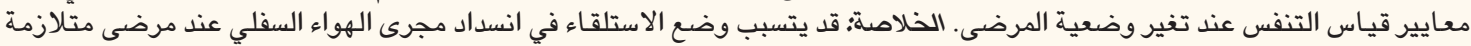

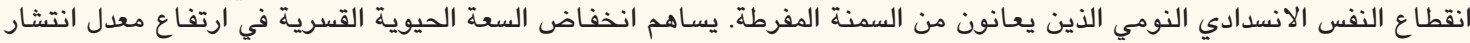
متلازمة انقطاع النفس الآنسدادي النومي النومي عند الذكور مقارنة بالنساء النساء.

الكلمات المفتاحية: انقطاع النفس الانسدادي النومي؛ السمنة؛ الجنس؛ معايير قياس التنفس؛ وضعية؛ عُمان. بأ.

\section{ADVANCES IN KNOWLEDGE}

Changing from a sitting to a supine position might affect the upper airway, possibly explaining the symptoms seen in patients with obstructive sleep apnoea syndrome such as snoring, snorting, apnoea episodes and early morning headaches.

Obesity could cause lower airway obstruction in addition to upper airway occlusion during sleep.

${ }^{1}$ Oman Medical Specialty Board, Muscat, Oman; Departments of ${ }^{2}$ Clinical Physiology and ${ }^{3}$ Family Medicine E Public Health, College of Medicine E Health Sciences, Sultan Qaboos University, Muscat, Oman; ${ }^{4}$ Formerly Department of Physiology, College of Medicine E Health Sciences, Sultan Qaboos University, Muscat, Oman

"Corresponding Author's e-mail: malabri@squ.edu.om 


\section{Application to Patient Care}

Obese male patients with OSAS are at risk of having lower airway obstruction, possibly worsening their nocturnal symptoms.

A change from a sitting to a supine position may cause lower airway obstruction in obese male patients with OSAS.

$\mathrm{O}$ BSTRUCTIVE SLEEP APNOEA SYNDROME (OSAS) is a growing health concern as it has been associated with a number of serious comorbidities particularly of the cardiovascular system. ${ }^{1,2}$ Sleep apnoea is defined as the cessation of airflow for a period of 10 seconds or more (apnoea) or diminished airflow accompanied by either $\geq 3 \%$ oxygen desaturation or awakening from sleep. ${ }^{3}$

OSAS is mainly related to obesity, which is defined as a body mass index (BMI) of more than 30 $\mathrm{kg} / \mathrm{m}^{2}{ }^{4}$ As the prevalence of obesity has increased, there has been a parallel increase in the prevalence of OSAS. ${ }^{5}$

The pathophysiology of OSAS is complex and not completely understood, particularly for non-obese OSAS patients. A narrowed upper airway is commonly seen in patients with OSAS and may be attributed to other factors such as fat deposition in the neck or abnormal bony morphology of the upper airway. ${ }^{6}$ Such defects may lead to functional impairment of the upper airway dilating muscles and alter airway diameter and transmural pressures. Even in non-obese subjects, the upper airway's diameter reduces in the supine posture.? This deficit is likely to be exaggerated in patients with OSAS, particularly while the individual is supine due to the effect of gravity. Spirometry and flow-volume loops have been used to detect the presence of airway obstruction in patients with OSAS..$^{8-11}$

Evidence suggests that overweight/obesity may also affect lung function in non-asthmatic subjects. ${ }^{11,12}$ The underlying mechanisms of these observations have not been adequately studied but it is believed to result from a complex interaction between mechanical and metabolic factors. For example, obesity affects the respiratory system by increasing the deposition of adipose tissue in the upper respiratory tract. These tissues start to produce adipokines, which are inflammatory substances, such as interleukin (IL)-1, IL-6 and tumour necrosis factor- $\alpha$. These inflammatory substances stimulate mucus secretion and may cause bronchospasms, leading to small airway obstructions. ${ }^{12}$

To the best of the authors' knowledge, this is the first study to use spirometry to assess the effect of change when moving from sitting to supine in patients with OSAS. The majority of previous studies focused on spirometry parameters in the erect position, yet none consider changes occurring in a supine position.

The hypothesis of the current study was that obese OSAS patients are more prone to develop lower airway obstruction compared to non-obese patients while changing position. In addition, this study examined the effect of age and gender on the degree of lower airway obstruction in OSAS patients while changing positions.

\section{Methods}

This cross-sectional study was conducted at Sultan Qaboos University Hospital (SQUH), Muscat, Oman, between December 2009 and December 2010. New patients who were over the age of 18 years and had been diagnosed with severe OSAS (apnoea-hypopnoea index >30) after one night of level-one polysomnography as per the standard criteria of the American Academy of Sleep Medicine were included in this study. ${ }^{13}$ All patients were OSAS treatment naïve and were nonasthmatic, non-smokers and free of chronic obstructive pulmonary disease and other cardiopulmonary diseases. Participants were not taking medication which may affect spirometry indices such as non-selective betablockers.

The patients reported to the pulmonary function testing laboratory, SQUH, between 10:00 and 11:00 $\mathrm{AM}$ to avoid time-related variation in spirometry parameters and had been asked to refrain from consuming caffeinated drinks on the day of the test.

Height and weight were measured at the time of arrival and BMI was calculated for all subjects. Subjects with a BMI of 18.5-25 were considered nonobese, while those with a BMI of 25-30 were classified as overweight; obese subjects were classed as having a BMI $>30 .{ }^{4}$ Participants were then split into two groups: obese (BMI >30) and non-obese (BMI = 18.5-30).

The spirometry device used (CPFS/D USB ${ }^{\mathrm{TM}}$ spirometer, MGC Diagnostics, Saint Paul, Minnesota, USA) measures and calculates forced expiratory volume in the first second (FEV1), forced vital capacity (FVC), FEV1/FVC and flow-volume curve parameters, forced expiratory flow (25-75\% and at 50\%; FEF), maximum forced inspiratory flow (FIFmax) and expiratory reserve volume (ERV) percentage. The spirometer used the software BreezeSuite, Version 8.5 (Medical Graphics Corporation, St. Paul, Minnesota, USA).

A three-litre calibration syringe was used to provide the calibration signal. Room temperature, relative humidity and barometric pressure were entered into the spirometer prior to starting the procedure. 
Table 1: Comparison of mean spirometry parameters between obese and non-obese obstructive sleep apnoea syndrome patients while changing from a sitting to supine position $(\mathrm{N}=27)$

\begin{tabular}{lccc}
$\begin{array}{l}\text { Spirometry } \\
\text { parameter in } \\
\text { percentage }\end{array}$ & $\begin{array}{c}\text { Non-obese } \\
(\mathbf{n}=9)\end{array}$ & $\begin{array}{c}\text { Obese } \\
(\mathbf{n}=\mathbf{1 8})\end{array}$ & P value \\
\hline FVC & $6.42 \pm 4.7$ & $3.95 \pm 2.85$ & 0.100 \\
FEV1 & $5.87 \pm 3.43$ & $5.48 \pm 2.7$ & 0.750 \\
FEV1/FVC & $-0.81 \pm 1.88$ & $1.58 \pm 1.72$ & 0.030 \\
FEF 25-75\% & $20.54 \pm 11.61$ & $21.03 \pm 9.09$ & 0.910 \\
FEF 50\% & $13.35 \pm 13.27$ & $13.86 \pm 11.08$ & 0.920 \\
FIFmax & $11.8 \pm 24.11$ & $5.65 \pm 12.36$ & 0.489 \\
ERV & $26.79 \pm 48.23$ & $25.68 \pm 49.03$ & 0.956
\end{tabular}

$S D=$ standard deviation $F V C=$ forced vital capacity; $F E V 1=$ forced expiratory volume in the first second; FEF = forced expiratory flow; FIFmax = maximum forced inspiratory flow; ERV = expiratory reserve volume.

Table 2: Comparison of absolute values of spirometry parameters between obese and non-obese obstructive sleep apnoea syndrome patients in sitting and supine positions $(\mathrm{N}=27)$

\begin{tabular}{|c|c|c|c|}
\hline \multirow{2}{*}{$\begin{array}{l}\text { Spirometry } \\
\text { parameter } \\
\text { in litre } \\
\text { (position) }\end{array}$} & \multicolumn{2}{|c|}{ Mean \pm SD } & \multirow[t]{2}{*}{$P$ value } \\
\hline & $\begin{array}{l}\text { Non-obese } \\
\quad(\mathbf{n}=9)\end{array}$ & $\begin{array}{l}\text { Obese } \\
(n=18)\end{array}$ & \\
\hline $\begin{array}{l}\text { FVC } \\
\text { (sitting) }\end{array}$ & $3.424 \pm 0.817$ & $3.187 \pm 1.165$ & 0.590 \\
\hline FVC (supine) & $3.214 \pm 0.839$ & $3.058 \pm 1.113$ & 0.714 \\
\hline $\begin{array}{l}\text { FEV1 } \\
\text { (sitting) }\end{array}$ & $2.883 \pm 0.700$ & $2.710 \pm 0.899$ & 0.618 \\
\hline $\begin{array}{l}\text { FEV1 } \\
\text { (supine) }\end{array}$ & $2.718 \pm 0.690$ & $2.562 \pm 0.855$ & 0.640 \\
\hline $\begin{array}{l}\text { FEV1/FVC } \\
\text { (sitting) }\end{array}$ & $84.111 \pm 4.755$ & $86.222 \pm 4.697$ & 0.283 \\
\hline $\begin{array}{l}\text { FEV1/FVC in } \\
\% \text { (supine) }\end{array}$ & $84.778 \pm 4.755$ & $84.833 \pm 4.274$ & 0.976 \\
\hline $\begin{array}{l}\text { FEF 25-75\% } \\
\text { (sitting) }\end{array}$ & $3.361 \pm 1.042$ & $3.322 \pm 1.028$ & 0.927 \\
\hline $\begin{array}{l}\text { FEF 25-75\% } \\
\text { (supine) }\end{array}$ & $2.677 \pm 0.914$ & $2.629 \pm 0.882$ & 0.897 \\
\hline $\begin{array}{l}\text { FEF 50\% } \\
\text { (sitting) }\end{array}$ & $4.144 \pm 1.199$ & $4.189 \pm 1.235$ & 0.932 \\
\hline $\begin{array}{l}\text { FEF 50\% } \\
\text { (supine) }\end{array}$ & $3.574 \pm 1.095$ & $3.597 \pm 1.191$ & 0.963 \\
\hline $\begin{array}{l}\text { FIFmax } \\
\text { (sitting) }\end{array}$ & $4.933 \pm 1.772$ & $4.605 \pm 1.742$ & 0.650 \\
\hline $\begin{array}{l}\text { FIFmax } \\
\text { (supine) }\end{array}$ & $4.162 \pm 1.444$ & $4.314 \pm 1.544$ & 0.807 \\
\hline $\begin{array}{l}\text { ERV } \\
\text { (sitting) }\end{array}$ & $0.664 \pm 0.312$ & $0.545 \pm 0.408$ & 0.448 \\
\hline ERV (supine) & $0.419 \pm 0.251$ & $0.359 \pm 0.319$ & 0.627 \\
\hline
\end{tabular}

$S D=$ standard deviation; $F V C=$ forced vital capacity; $F E V 1=$ forced expiratory volume in the first second; FEF = forced expiratory flow; FIFmax = maximum forced inspiratory flow; ERV = expiratory reserve volume.
The device reported all values at body temperature and pressure saturated with water vapour. Spirometry was performed based on the standards and guidelines of the American Thoracic Society. ${ }^{14}$

The subjects breathed 5-6 times at tidal volume and then breathed in maximally and breathed out maximally to residual volume. The procedure was done while patients were supine and while they were sitting. A new pneumotach and nose clip were used for each patient to avoid contamination through saliva or body fluids.

All participants performed the slow vital capacity (SVC) and FVC manoeuvers thrice while sitting and thrice while supine. Three minutes were given between each FVC trial. The best effort in each posture was included for the analysis.

The data were analysed using Statistical Package for the Social Sciences (SPSS), Version 23 (IBM Corp., Armonk, New York, USA). Normality of the parameters under study was checked using a Kolmogorov-Smirnov one sample test; if the distribution pattern was normal, then an independent samples t-test was used to evaluate the significance of the difference between the means of the two groups. If the distribution pattern was not normal, then the non-parametric MannWhitney-U test was used to determine the equality of the two groups. A $P$ value of $\leq 0.05$ was considered statistically significant.

Changes in spirometry parameters were calculated using the following formula:

$$
\text { mean percentage }=[(\text { sitting-supine }) / \text { sitting })^{*} 100
$$

The mean difference in change of position from sitting and supine positions was compared based on BMI, age and gender.

Informed consent was obtained from all participants and the study was explained. Participants could withdraw from the study at any time. The study was approved by the Medical Research \& Ethics Committee of the College of Medicine \& Health Sciences, SQUH (MREC \#488).

\section{Results}

A total of 27 OSAS patients were included in this study, the majority of which were male (70.4\%). The mean male patient age was $40.32 \pm 9.68$ years, the mean male BMI was $32.11 \pm 4.83 \mathrm{~kg} / \mathrm{m}^{2}$ and the mean male apnoea/hypopnoea index was $49.01 \pm 23.78$. The mean female patient age was $47.63 \pm 7.21$ years, the mean female BMI was $37.26 \pm 4.55 \mathrm{~kg} / \mathrm{m}^{2}$ and the mean female apnoea/hypopnoea index was $53.05 \pm 18.31$. There was a significant difference in BMI $(P=0.02)$ but not age $(P=0.07)$ or apnoea/hypopnoea index $(P=0.67)$ between 
Table 3: Comparison of absolute values of spirometry parameters between patients less than and more than 40 years old when changing from sitting to supine position $(\mathrm{N}=27)$

\begin{tabular}{lccc}
$\begin{array}{l}\text { Spirometry } \\
\text { parameter } \\
\text { in litre } \\
\text { (position) }\end{array}$ & $\begin{array}{c}\text { M40 years } \\
(\mathbf{n}=\mathbf{1 1})\end{array}$ & $\begin{array}{c}>40 \text { years } \\
(\mathbf{n}=\mathbf{1 6})\end{array}$ & \\
\hline FVC (sitting) & $3.916 \pm 0.947$ & $2.819 \pm 0.892$ & 0.005 \\
\hline $\begin{array}{l}\text { FVC (supine) } \\
\text { FEV1 (sitting) }\end{array}$ & $3.716 \pm 0.965$ & $2.694 \pm 0.845$ & 0.007 \\
$\begin{array}{l}\text { FEV1 (supine) } \\
\text { FEV1/FVC in }\end{array}$ & $3.134 \pm 0.715$ & $2.258 \pm 0.647$ & 0.003 \\
\% (sitting) & $85.909 \pm 4.437$ & $85.250 \pm 5.053$ & 0.730 \\
$\begin{array}{l}\text { FEV1/FVC in } \\
\% \text { (supine) }\end{array}$ & $85.000 \pm 4.450$ & $84.688 \pm 4.438$ & 0.859 \\
$\begin{array}{l}\text { FEF 25-75\% } \\
\text { (sitting) }\end{array}$ & $4.065 \pm 1.022$ & $2.833 \pm 0.650$ & 0.001 \\
$\begin{array}{l}\text { FEF 25-75\% } \\
\text { (supine) }\end{array}$ & $3.191 \pm 0.981$ & $2.269 \pm 0.564$ & 0.005 \\
$\begin{array}{l}\text { FEF 50\% } \\
\text { (sitting) }\end{array}$ & $4.751 \pm 1.083$ & $3.753 \pm 1.132$ & 0.033 \\
$\begin{array}{l}\text { FEF 50\% } \\
\text { (supine) }\end{array}$ & $4.154 \pm 1.209$ & $3.176 \pm 0.919$ & 0.028 \\
$\begin{array}{l}\text { FIFmax } \\
\text { (sitting) }\end{array}$ & $5.015 \pm 1.438$ & $4.508 \pm 1.915$ & 0.464 \\
$\begin{array}{l}\text { FIFmax } \\
\text { (supine) }\end{array}$ & $4.729 \pm 1.451$ & $3.944 \pm 1.466$ & 0.182 \\
$\begin{array}{l}\text { ERV (sitting) } \\
\text { ERV (supine) }\end{array}$ & $0.548 \pm 0.350$ & $0.263 \pm 0.182$ & 0.026 \\
\hline
\end{tabular}

$S D=$ standard deviation; $F V C=$ forced vital capacity; FEV1 = forced expiratory volume in the first second; FEF = forced expiratory flow; FIFmax = maximum forced inspiratory flow; ERV = expiratory reserve volume.

Table 4: Comparison of mean spirometry parameters between patients less than and more than 40 years old when changing from sitting to supine position $(\mathrm{N}=27)$

$\begin{array}{lccc}\begin{array}{l}\text { Spirometry } \\ \text { parameter in } \\ \text { percentage }\end{array} & \begin{array}{c}\text { <40 years } \\ (\mathbf{n}=\mathbf{1 1})\end{array} & \begin{array}{c}>\text { 40 years } \\ (\mathbf{n}=\mathbf{1 6})\end{array} & \text { P value } \\ \text { FVC } & 5.35 \pm 4.50 & 4.37 \pm 3.09 & 0.504 \\ \text { FEV1 } & 6.44 \pm 3.22 & 5.04 \pm 2.62 & 0.225 \\ \text { FEV1/FVC } & 1.04 \pm 2.15 & 0.60 \pm 2.09 & 0.600 \\ \text { FEF 25-75\% } & 22.02 \pm 10.04 & 20.06 \pm 9.84 & 0.619 \\ \text { FEF 50\% } & 12.94 \pm 10.94 & 14.27 \pm 12.29 & 0.778 \\ \text { FIFmax } & 6.51 \pm 12.16 & 8.51 \pm 19.95 & 0.770 \\ \text { ERV } & 34.90 \pm 26.58 & 19.96 \pm 58.29 & 0.378\end{array}$

$S D=$ standard deviation $F V C=$ forced vital capacity $F E V 1=$ forced expiratory volume in the first second; FEF = forced expiratory flow; FIFmax = maximum forced inspiratory flow; $E R V=$ expiratory reserve volume.

the genders. The mean patient age was $41.82 \pm 9.69$ years and mean BMI was $33.68 \pm 5.44 \mathrm{~kg} / \mathrm{m}^{2}$.

There was no significant difference in FVC or FEV1 between non-obese and obese OSAS patients in sitting and supine positions or when changing posture
Table 5: Comparison of absolute values of spirometry parameters between male and female obstructive sleep apnoea syndrome patients in sitting and supine positions $(\mathrm{N}=27)$

\begin{tabular}{lccc}
$\begin{array}{l}\text { Spirometry } \\
\text { parameter } \\
\text { in litre } \\
\text { (position) }\end{array}$ & $\begin{array}{c}\text { Male } \\
(\mathbf{n}=19)\end{array}$ & $\begin{array}{c}\text { Female } \\
(\mathbf{n}=\mathbf{8})\end{array}$ & \\
\hline FVC (sitting) & $3.689 \pm 0.915$ & $2.261 \pm 0.562$ & $<0.001$ \\
FVC (supine) & $3.490 \pm 0.918$ & $2.209 \pm 0.588$ & 0.001 \\
FEV1 (sitting) & $3.096 \pm 0.724$ & $1.988 \pm 0.460$ & 0.001 \\
FEV1 & $2.915 \pm 0.710$ & $1.900 \pm 0.463$ & 0.001 \\
(supine) & & & \\
$\begin{array}{l}\text { FEV1/FVC in } \\
\% \text { (sitting) }\end{array}$ & $84.316 \pm 4.820$ & $88.375 \pm 3.204$ & 0.039 \\
$\begin{array}{l}\text { FEV1/FVC in } \\
\% \text { (supine) }\end{array}$ & $84.000 \pm 4.333$ & $86.750 \pm 3.204$ & 0.137 \\
$\begin{array}{l}\text { FEF 25-75\% } \\
\text { (sitting) }\end{array}$ & $3.585 \pm 1.077$ & $2.743 \pm 0.510$ & 0.046 \\
$\begin{array}{l}\text { FEF 25-75\% } \\
\text { (supine) }\end{array}$ & $2.836 \pm 0.924$ & $2.191 \pm 0.562$ & 0.080 \\
$\begin{array}{l}\text { FEF 50\% } \\
\text { (sitting) }\end{array}$ & $4.528 \pm 1.207$ & $3.380 \pm 0.750$ & 0.021 \\
$\begin{array}{l}\text { FEF 50\% } \\
\text { (supine) }\end{array}$ & $3.912 \pm 1.197$ & $2.864 \pm 0.541$ & 0.027 \\
$\begin{array}{l}\text { FIFmax } \\
\text { (sitting) }\end{array}$ & $5.232 \pm 1.725$ & $3.486 \pm 0.975$ & 0.013 \\
$\begin{array}{l}\text { FIFmax } \\
\text { (supine) }\end{array}$ & $4.595 \pm 1.530$ & $3.476 \pm 1.080$ & 0.073 \\
ERV (sitting) & $0.733 \pm 0.349$ & $0.232 \pm 0.107$ & $<0.001$ \\
ERV (supine) & $0.456 \pm 0.314$ & $0.195 \pm 0.119$ & 0.004 \\
\hline
\end{tabular}

$S D=$ standard deviation; $F V C=$ forced vital capacity; $F E V 1=$ forced expiratory volume in the first second; FEF = forced expiratory flow; FIFmax = maximum forced inspiratory flow; $E R V=$ expiratory reserve volume.

Table 6: Comparison of mean spirometry parameters between male and female obstructive sleep apnoea syndrome patients when changing from a sitting to supine position $(\mathrm{N}=27)$

$\begin{array}{lccc}\begin{array}{l}\text { Spirometry } \\ \text { parameter in } \\ \text { percentage }\end{array} & \begin{array}{c}\text { Male } \\ (\mathbf{n}=\mathbf{1 9})\end{array} & \begin{array}{c}\text { Female } \\ (\mathbf{n}=\mathbf{8})\end{array} & \text { P value } \\ \text { FVC } & 5.66 \pm 3.65 & 2.66 \pm 2.95 & 0.050 \\ \text { FEV1 } & 6.03 \pm 2.93 & 4.61 \pm 2.74 & 0.254 \\ \text { FEV1/FVC } & 0.32 \pm 2.21 & 1.87 \pm 1.63 & 0.077 \\ \text { FEF 25-75\% } & 20.99 \pm 9.78 & 20.553 \pm 10.43 & 0.917 \\ \text { FEF 50\% } & 13.66 \pm 11.07 & 13.79 \pm 13.31 & 0.979 \\ \text { FIFmax } & 10.66 \pm 18.32 & 0.652 \pm 11.13 & 0.166 \\ \text { ERV } & 30.22 \pm 52.31 & 16.14 \pm 36.07 & 0.496\end{array}$

$S D=$ standard deviation $F V C=$ forced vital capacity; $F E V 1=$ forced expiratory volume in the first second; FEF = forced expiratory flow; FIFmax = maximum forced inspiratory flow; ERV = expiratory reserve volume.

from a sitting to a supine position. However, there was a significant difference in the change of FEV1/FVC between obese and non-obese subjects (-0.81\% versus $1.58 \% ; P=0.030)$. There was no significant difference 
in the remaining parameters with change of posture or with absolute values [Tables 1 and 2].

There was a significant difference between the patients who were $\leq 40$ years old and $>40$ years old in all absolute values of the spirometry parameters in sitting and supine positions $(P<0.05)$ except FEV1/ FVC and FIFmax $(P>0.05)$. There was no significant difference between the two groups when changing posture in any of the spirometry parameters $(P>0.05)$ [Tables 3 and 4].

There was a significant difference between gender in all absolute values of the spirometry parameters $(P<0.05)$ except FEV1/FVC in the supine position, FEF $25-75 \%$ in the supine position and FIFmax in a supine position $(P>0.05)$. There was a significant difference between male and female participants in the change of FVC while changing position from a sitting to supine $(5.66 \pm 3.65$ versus $2.66 \pm 2.95 ; P=0.050)$. Other parameters did not show any significant differences between genders with change of position [Tables 5 and 6].

\section{Discussion}

Spirometry and flow-volume loops are simple, commonly used tests in patients with respiratory diseases. This study aimed to examine the effect of a change of position on the reactivity of airways in OSAS patients with different risk factors such as obesity, age and gender.

No significant difference was found in FEV1/FVC when changing from sitting to supine positions between obese and non-obese OSAS patients. This finding can be attributed to a greater reduction of FVC in obese subjects. Nevertheless, no significant difference was found between the two groups with absolute values of spirometry parameters in either position. This finding would support the initial assumption that obesity may predispose individuals with OSAS to an obstructive airway pattern when moving from a sitting to supine position. This may be due to the limited mobility of the diaphragm and chest wall when in a supine position. ${ }^{15}$ The current study contradicts Hoffstein et al's findings that sleep apnoea is unrelated to pulmonary function measured during wakefulness. ${ }^{16}$ However, Hoffstein et al. studied a larger cohort compared to the current sample size and measured the spirometry parameters in one position only while the current study examined the difference resulting from a change in position. ${ }^{16}$

In the current study, a significant difference was found in absolute values for most of the spirometry parameters in both positions when comparing OSAS patients who were less than or more than 40 years old.
This finding may be attributed to the effect of age on lung functions. However, no significant changes were found in the mean differences of those parameters between the two groups. Previous studies have indicated, that with age, all spirometry parameters decrease which could be attributed to a decrease in elastic recoil and stiffening of the chest wall. ${ }^{17}$ This decline, however, mostly occurs after the age of 60 according to Medbø and Melbye. ${ }^{18}$ Other explanations for this finding could be that aging does not cause lower airway obstruction while changing position. Further studies are required to confirm this phenomenon.

An additional risk factor for OSAS is being male. ${ }^{19}$ In the current study there was a weak significant difference of the percentage decrease in FVC when comparing male and female patients with no significant increase in FEV1/FVC. Males have been found to be more prone to develop severe OSAS due to anatomical factors and impaired ventilatory control during sleep. ${ }^{19}$ In addition, men have a greater abdominal fat distribution than women, which may explain less frequent FVC and FEV1. ${ }^{15}$

When comparing OSAS patients in different positions, significant differences were found between different factors. Campbell et al. compared OSAS patients and patients with brief upper airway dysfunction (BUAD) with normal subjects and found no difference in flow-volume curve indices. ${ }^{20}$ However, they eliminated the confounders of obesity and age which were the main variables under comparison in the current study. Nevertheless, Campbell et al's study measured the flow-volume curve in different positions as did the current study. Campbell et al's main aim was to predict OSAS and BUAD from changes in flowvolume curve which differs from the current study which examines the relationship between changes in spirometry parameters and changes in posture in patients with severe OSAS.

The current study has limitations. A major limitation is the study's small sample size which might have affected the statistical reliability of the comparisons. Additionally, OSAS patients were not compared with non-OSAS subjects. However, it is extremely difficult to find obese subjects without OSAS. Obesity was measured in only one way and should have been measured by different means such as waist/hip ratio and neck circumference in order to determine whether the patient is truly obese. For example, patients with high muscle mass can have a high BMI but not be obese. While the current study examined the spirometry indices of patients with OSAS in two positions, adding a standing position in future studies would add more value to this type of examination. 


\section{Conclusion}

A supine position may increase lower airway obstruction in obese patients with OSAS. However, in patients with OSAS, age and, to a lesser extent, gender did not have a large impact on spirometry parameters while changing between sitting and supine positions.

\section{CONFLICT OF INTEREST}

The authors declare no conflicts of interest.

\section{FUNDING}

No funding was received for this study.

\section{References}

1. Young T, Finn L. Epidemiological insights into the public health burden of sleep disordered breathing: Sex differences in survival among sleep clinic patients. Thorax 1998; 53:S16-19. https://doi.org/10.1136/thx.53.2008.s16.

2. Kuniyoshi FH, Pusalavidyasagar S, Singh P, Somers VK Cardiovascular consequences of obstructive sleep apnoea. Indian J Med Res 2010; 131:196-205.

3. Guilleminault C, Tilkian A, Dement WC. The sleep apnea syndromes. Annu Rev Med 1976; 27:465-84. https://doi.org/10.1146/ annurev.me.27.020176.002341.

4. Guyton A, Hall J. Obesity. In: Guyton AC, Hall JE, Eds. Text Book of Medical Physiology. 11th ed. Philadelphia: Elsevier Saunders, 2006. Pp. 872-3.

5. Tintinger GR, Pretorius L, Labadarios D. Obstructive sleep apnoea and obesity. South Afr J Clin Nutr 2011; 24:174-7. https://doi.org/10.1080/16070658.2011.11734384.

6. Deegan PC, McNicholas WT. Pathophysiology of obstructive sleep apnoea. Eur Respir J 1995; 8:1161-78. https://doi.org/10.11 83/09031936.95.08071161.

7. Hudgel DW. Mechanisms of obstructive sleep apnea. Chest 1992; 101:541-9. https://doi.org/10.1378/chest.101.2.541.

8. Jan MA, Marshall I, Douglas NJ. Effect of posture on upper airway dimensions in normal human. Am I Respir Crit Care Med 1994; 149:145-8. https://doi.org/10.1164/ajrccm.149.1.81 11573.
9. Haponik EF, Bleecker ER, Allen RP, Smith PL, Kaplan J. Abnormal inspiratory flow-volume curves in patients with sleep-disordered breathing. Am Rev Respir Dis 1981; 124:571-4.

10. Owens GR, Murphy DM. Spirometric diagnosis of upper airway obstruction. Arch Intern Med 1983; 143:1331-4. https://doi. org/10.1001/archinte.1983.00350070047008.

11. Shore ET, Millman RP. Abnormalities in the flow-volume loop in obstructive sleep apnoea sitting and supine. Thorax 1984; 39:775-9. https://doi.org/10.1136/thx.39.10.775.

12. McCoy EK, Thomas JL, Sowell RS, George C, Finch CK, Tolley EA, et al. An evaluation of peak expiratory flow monitoring: A comparison of sitting versus standing measurements. J Am Board Fam Med 2010; 23:166-70. https://doi.org/10.3122/ jabfm.2010.02.090120.

13. Kapur VK, Auckley DH, Chowdhuri S, Kuhlmann DC, Mehra R, Ramar K, et al. Clinical practice guideline for diagnostic testing for adult obstructive sleep apnea: An American Academy of Sleep Medicine clinical practice guideline. J Clin Sleep Med 2017; 13:479-504. https://doi.org/10.5664/jcsm.6506.

14. Aggarwal AN, Agarwal R. The new ATS/ERS guidelines for assessing the spirometric severity of restrictive lung disease differ from previous standards. Respirology 2007; 12:759-62. https://doi.org/10.1111/j.1440-1843.2007.01117.x.

15. Melo LC, Silva MA, Calles AC. Obesity and lung function: A systematic review. Einstein (Sao Paulo) 2014; 12:120-5. https://doi.org/10.1590/S1679-45082014RW2691.

16. Hoffstein V, Oliver Z. Pulmonary function and sleep apnea. Sleep Breath 2003; 7:159-65. https://doi.org/10.1007/s11325003-0159-8.

17. Hassel E, Stensvold D, Halvorsen T, Wisløff U, Langhammer A, Steinshamn S. Association between pulmonary function and peak oxygen uptake in elderly: The Generation 100 study. Respir Res 2015; 16:156. https://doi.org/10.1186/s12931-015-0317-0.

18. Medbø A, Melbye H. Lung function testing in the elderly--Can we still use FEV1/FVC $<70 \%$ as a criterion of COPD? Respir Med 2007; 101:1097-105. https://doi.org/10.1016/j.rmed.2006.11.019.

19. Joosten SA, Khoo JK, Edwards BA, Landry SA, Naughton MT, Dixon JB, et al. Improvement in obstructive sleep apnea with weight loss is dependent on body position during sleep. Sleep 2017; 40. https://doi.org/10.1093/sleep/zsx047.

20. Campbell AH, Guy PA, Rochford PD, Worsnop CJ, Pierce RJ. Flow-volume curve changes in patients with obstructive sleep apnoea and brief upper airway dysfunction. Respirology 2000; 5:11-18. https://doi.org/10.1046/j.1440-1843.2000.00220.x. 